\title{
Antoine Furetière, Nouvelle Allégorique ou Histoire des derniers troubles arrivés au Royaume d'éloquence
}

\section{Laura Rescia}

\section{(2) OpenEdition}

1 Journals

\section{Edizione digitale}

URL: http://journals.openedition.org/studifrancesi/34637

DOI: 10.4000/studifrancesi.34637

ISSN: 2421-5856

\section{Editore}

Rosenberg \& Sellier

\section{Edizione cartacea}

Data di pubblicazione: 1 novembre 2005

Paginazione: 412

ISSN: 0039-2944

\section{Notizia bibliografica digitale}

Laura Rescia, «Antoine Furetière, Nouvelle Allégorique ou Histoire des derniers troubles arrivés au Royaume d'éloquence», Studi Francesi [Online], 146 (XLIX | II) | 2005, online dal 30 novembre 2015, consultato il 18 avril 2021. URL: http://journals.openedition.org/studifrancesi/34637 ; DOI: https:// doi.org/10.4000/studifrancesi.34637

Questo documento è stato generato automaticamente il 18 avril 2021.

\section{(c)}

Studi Francesi è distribuita con Licenza Creative Commons Attribuzione - Non commerciale - Non opere derivate 4.0 Internazionale. 


\title{
Antoine Furetière, Nouvelle Allégorique ou Histoire des derniers troubles arrivés au Royaume d'éloquence
}

\author{
Laura Rescia
}

\section{NOTIZIA}

ANTOINE FURETIÈRE, Nouvelle Allégorique ou Histoire des derniers troubles arrivés au Royaume d'éloquence, éd. M. Bombart et N. Schapira, Collection de rééditions de textes rares du

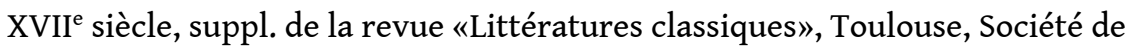
Littératures Classiques, 2004, pp. XXXVIII, 73.

1 Comparso nel 1658, nello stesso anno rieditato, il racconto allegorico della guerra tra la Principessa Rhétorique e il Principe Galimatias è notoriamente un testo fruibile a più livelli. Attraverso la descrizione satirica delle istituzioni e del mondo letterario contemporaneo, intessuta di citazioni esplicite o implicite ad autori e opere, lo sguardo di Furetière rivela una propensione realistica, unitamente ad una valenza metaletteraria e metalinguistica, emergente nelle pagine di riflessione dedicate alla poetica e alla retorica. Lontano da ogni preoccupazione prescrittiva, l'interesse di Furetière sui meccanismi letterari e sulla lingua, qui rappresentata in molte delle sue varianti sociali, lessicali e stilistiche, anticipa il lavoro del lessicografo di fine secolo.

2 La presente edizione, curata da M. Bombart e N. Shapira (la seconda edizione moderna del testo integrale, già proposto a cura di E. van Ginneken nel 1967 per la collana «Textes littéraires français» di Droz) intende precisamente mettere in luce la metariflessione dell'autore, le cui note a margine vengono riproposte (unitamente alle varianti della seconda edizione del 1659) come primo livello di amplificazione del testo. Gli editori scientifici limitano le loro note all'elucidazione di qualche punto rimasto 
oscuro, e a interessanti rinvii concettuali tra la novella e il dizionario, che la critica ha già visto come posti su una stessa linea di sviluppo. Nell'introduzione al testo, il lettore troverà un rapido inquadramento sulla tradizione in cui esso si inscrive, sulla moda della cartografia allegorica propria del Grand Siècle, sulle ambiguità del testo - ancora aperto ad ipotesi interpretative - sulle reazioni del mondo letterario alla comparsa della novella, e in particolare sulla risposta di Charles Sorel nella sua Rélation véritable de ce qui s'est passé au royaume de Sophie. L'indice dei nomi, adeguatamente curato, rende tale edizione un comodo strumento di lavoro. 